\title{
Diarrhoea in jaundiced neonates treated with phototherapy: role of intestinal secretion
}

\author{
M DE CURTIS, S GUANDALINI, A FASANO, F SAITTA, AND F CICCIMARRA
}

Department of Paediatrics, Second School of Medicine, University of Naples, Italy

SUMMARY Thirty jaundiced neonates with diarrhoea who were being treated with phototherapy and 30 matched control infants were studied to try and find out the cause of the diarrhoea. Faecal osmolality and electrolyte concentrations were measured, which gave clear evidence that the diarrhoea arose from intestinal secretion. Rectal water and electrolyte absorption in 10 jaundiced infants receiving phototherapy, in 10 jaundiced infants not receiving phototherapy, and in 10 healthy controls was measured with a rectal dialysis bag. A further group of eight jaundiced infants was also studied both during and after phototherapy to document the reversal of ion transport changes. Absorption of water, sodium chloride, and potassium was significantly impaired in the patients receiving phototherapy compared with each of the control groups. Such impairment was transient, as it was not apparent when the jaundice faded and phototherapy was stopped. These data show that the colon plays a part in the pathogenesis of secretory diarrhoea and that both hyperbilirubinaemia and phototherapy are necessary for such an effect to develop.

Since Cremer introduced phototherapy for the treatment of neonatal jaundice, the presence of watery and greenish stools has often been reported in neonates receiving phototherapy. ${ }^{1}$ The pathogenesis of this complication is unclear. In 1977, Bakken reported a temporary lactase deficiency in six jaundiced infants treated in this way, which he attributed to the mucosal injury ${ }^{2}$; this finding was not confirmed, later on, by Ebbesen nor, more recently, by Bujanover et al. ${ }^{3-5}$

On the basis of the results of measurement of stool electrolytes and osmolality in 10 jaundiced babies receiving phototherapy, we suggested that the diarrhoea might be secretory. ${ }^{6}$ In the present report we extend those preliminary observations and present evidence of secretory changes induced by phototherapy in the distal colon of babies-that is, the only segment of the gastrointestinal tract that we consider it ethical to investigate in newborn infants.

\section{Patients and methods}

We measured faecal osmolality and electrolyte concentrations in 30 newborn infants with uncomplicated hyperbilirubinaemia (mean (SEM) serum bilirubin $265(3.4) \mu \mathrm{mol} / \mathrm{l})$ who had diarrhoea when exposed to blue light at $650-700 \mu \mathrm{W} / \mathrm{cm}^{2}$ and in 30 healthy newborn infants who had neither jaundice nor diarrhoea.

There were no significant differences in mean (SEM) birth weight (3462 (88) and 3526 (109) g), gestational age $(39.3(0.3)$ and $39.4(0.3)$ weeks), postnatal age at beginning of the study (76 (2) and 64 (2) hours) between the two groups. All infants were breast fed, and feeding regimens were the same in both groups. Hyperbilirubinaemic infants had a mean bilirubin concentration at the time of the study of 274 (17) $\mu \mathrm{mol} / 1$ and received phototherapy for 16 (2) hours.

In a separate series of experiments we studied the absorption of electrolytes in the rectum by a modification of the non-equilibrium dialysis method of Edmonds and Godfrey ${ }^{8}$ in 10 jaundiced infants with diarrhoea receiving phototherapy, 10 jaundiced infants not receiving phototherapy, and 10 healthy controls. The groups were well matched for birth weight, gestational age, and age at the beginning of the study (table 1). Mean (SEM) serum bilirubin concentration at the study was $257(5) \mu \mathrm{mol} / \mathrm{l}$ in the group treated with phototherapy and 238 (3) $\mu \mathrm{mol} / 1$ in the group not so treated; it was 94 (7) $\mu \mathrm{mol} / \mathrm{l}$ in the group that was not jaundiced. Phototherapy was given for 18 (3) hours.

In addition, to obtain direct evidence that electrolyte transport changes were associated with photo- 
Table 1 Details of infants studied. Values are expressed as mean (SEM)

\begin{tabular}{|c|c|c|c|}
\hline & $\begin{array}{l}\text { Birth weight } \\
(g)\end{array}$ & $\begin{array}{l}\text { Gestational age } \\
\text { (weeks) }\end{array}$ & $\begin{array}{l}\text { Age at beginning } \\
\text { of study (hours) }\end{array}$ \\
\hline Jaundiced infants receiving phototherapy $(n=10)$ & $3402 \quad(95)$ & $38.9(0.2)$ & $88(3)$ \\
\hline Jaundiced infants not receiving phototherapy $(n=10)$ & $3368(146)$ & $39.6(0.3)$ & $86(3)$ \\
\hline Infants not jaundiced $(n=10)$ & $3547(67)$ & $39.2(0.4)$ & $83(3)$ \\
\hline
\end{tabular}

therapy, we investigated eight breast fed newborn infants both during phototherapy and after they had completed it. They had a mean (SEM) birth weight of $3360(158) \mathrm{g}$ and gestational age of $39.0(0 \cdot 6)$ weeks. They were investigated with the dialysis technique at 85 (5) hours of life while receiving phototherapy, and their mean serum bilirubin concentration was 274 (7) $\mu \mathrm{mol} / \mathrm{l}$. They were then reexamined when they were $129(5)$ hours old after phototherapy had been discontinued, and the concentration had dropped to 178 (9) $\mu \mathrm{mol} / \mathrm{l}$.

The experimental technique consisted of insertion into the rectum of a weighed dialysis bag $\left(5.3 \mathrm{~cm}^{2}\right)$ made from visking tube and mounted on a $6 \mathrm{~F}$ gauge nasogastric tube. The bag was filled with an isotonic electrolyte solution containing sodium $140 \mathrm{mmol} / \mathrm{l}$, potassium $20 \mathrm{mmol} / \mathrm{l}$, chloride $130 \mathrm{mmol} / \mathrm{l}$, and bicarbonate $30 \mathrm{mmol} / \mathrm{l}$. After being positioned the bag was left in situ for 30 minutes and then removed and reweighed. The sodium and potassium concentrations were measured by flame photometry and chloride by a chloridometer. The observed changes

Table 2 Stool osmolality and electrolyte concentrations. Values are expressed as mean (SEM)

\begin{tabular}{llrl}
\hline & $\begin{array}{l}\text { Jaundiced } \\
\text { infants } \\
\text { receiving } \\
\text { phototherapy } \\
(n=30)\end{array}$ & $\begin{array}{l}\text { Healthy } \\
\text { infants } \\
(n=30)\end{array}$ & $\begin{array}{l}p \\
\text { Value }\end{array}$ \\
& & & \\
\hline Stool osmolality (mOsm/l) & $269(10)$ & $284(13)$ & $>0 \cdot 1$ \\
Sodium (mmol/l) & $63(4)$ & $38(6)$ & $<0.001$ \\
Potassium (mmol/l) & $52(3)$ & $31(5)$ & $<0.001$ \\
Anion gap (mmol/l) & $37(4)$ & $144(17)$ & $<0.001$ \\
\hline
\end{tabular}

in weight and in electrolyte content were finally calculated and assumed to represent net fluxes (either absorptive or secretory) of water and electrolytes, respectively.

Values are expressed as mean (SEM). The significance of the differences was calculated by Student's $t$ test for either paired or unpaired variables, as appropriate. Informed consent was obtained from all the parents.

\section{Results}

Table 2 shows the mean (SEM) values of stool osmolality and electrolytes in the 30 jaundiced infants with diarrhoea who were receiving phototherapy, and in the 30 healthy controls. The data on electrolyte concentration and the anion gap are consistent with a secretory pattern for the diarrhoea.

Table 3 shows the net absorption of water and electrolytes in the 10 jaundiced infants with diarrhoea who were receiving phototherapy, in the 10 jaundiced infants not receiving phototherapy, and in the 10 healthy control infants. A clear inhibition of absorption of water and electrolytes was seen in jaundiced infants receiving phototherapy. Such inhibition is highly significant in comparison with each of the two control groups (the jaundiced infants not receiving phototherapy and the healthy infants).

Table 4 shows the net absorption of water and electrolytes in the eight infants who were studied during and after phototherapy. It is evident that the inhibition of water and electrolyte absorption found during phototherapy completely disappeared after it had been stopped, and the jaundice had regressed.

Table 3 Rectal net absorption of water and electrolytes. Values are expressed as mean (SEM)

$\left.\begin{array}{lllll}\hline & \begin{array}{l}\text { Jaundiced infants } \\ \text { receiving } \\ \text { phototherapy } \\ (n=10)\end{array} & \begin{array}{l}p \\ \text { Value }\end{array} & \begin{array}{l}\text { Jaundiced neonates } \\ \text { not receiving } \\ \text { phototherapy } \\ (n=10)\end{array} & \begin{array}{l}\text { Neonates } \\ \text { Value }\end{array} \\ \text { naundiced } \\ (n=10)\end{array}\right)$

${ }^{*} \mathrm{p}<0 \cdot 01$ when compared with neonates not jaundiced. 
Table 4 Net absorption of water and electrolytes during and after phototherapy. Values are expressed as mean (SEM)

\begin{tabular}{lllll}
\hline & $\begin{array}{l}\text { Water } \\
\left(\mu \mathrm{l} / \mathrm{min} / \mathrm{cm}^{2}\right)\end{array}$ & $\begin{array}{l}\text { Sodium } \\
\left(\mu \mathrm{mol} / \mathrm{min} / \mathrm{cm}^{2}\right)\end{array}$ & $\begin{array}{l}\text { Chloride } \\
\left(\mu \mathrm{mol} / \mathrm{min} / \mathrm{cm}^{2}\right)\end{array}$ & $\begin{array}{l}\text { Potassium } \\
\left(\mu \mathrm{mol} / \mathrm{min} / \mathrm{cm}^{2}\right)\end{array}$ \\
\hline $\begin{array}{llll}\text { During phototherapy } \\
\text { After phototherapy }\end{array}$ & $2 \cdot 6(0 \cdot 1)$ & $248(8)$ & $266(8)$ & $6(1)$ \\
p Value & $3 \cdot 6(0 \cdot 2)$ & $308(9)$ & $329(11)$ & $13(3)$ \\
\hline
\end{tabular}

\section{Discussion}

The aim of our work was twofold: to extend and confirm our preliminary report that had suggested the secretory nature of the diarrhoea found in jaundiced infants receiving phototherapy, ${ }^{6}$ and to verify whether secretory changes could be found in an intestinal segment as supporting evidence for such a mechanism.

The data reported here in 60 more infants both confirm our earlier observations on the changes in stool electrolytes and osmolality in jaundiced neonates receiving phototherapy, and set reference values for such measurements in breast fed neonates born at full term. The observation of normal osmolality and of a small anion gap in the faeces of the study group permits the ruling out of the presence of osmotically active substances, and thus according to Krejis and Fordtran, ${ }^{9}$ the pathogenetic mechanism of the diarrhoea can be traced to intestinal secretion. In this respect the rather large value for the anion gap found in the stools of normal babies needs to be commented upon.

Osmotically active solutes in the faeces of breast fed infants are likely to be represented by digestive break down products that are not absorbed. In such neonates, particularly during the first week of life, substantial amounts of reducing substances are lost in the stools. It has also been shown that oligosaccharides, which appear in comparatively high concentrations in human colostrum and milk (24 and 12 $\mathrm{g} / \mathrm{l}$, respectively) are poorly absorbed. ${ }^{10} 11$

We chose to evaluate water and electrolyte transport in the rectum with the dialysis method, as no other method was, in our view, sufficiently non-invasive to be used in healthy infants. The results we obtained show a pronounced impairment of absorptive rates of water and ions in jaundiced infants receiving phototherapy, compared with both jaundiced infants not so treated and the healthy control infants. Furthermore, the reversal of such alterations observed in the same babies after the jaundice had faded and the phototherapy been stopped provides compelling evidence that the antiabsorptive changes are indeed related to jaundice and phototherapy.
Although we did not actually observe secretion, diarrhoea may arise from simple impairment of absorption, which may be sufficient in itself to reverse the overall net water balance. ${ }^{9}$ Furthermore, it is possible that the shift towards secretion that we found in the rectum is also present and in greater magnitude in more proximal segments, including the small bowel, which we did not investigate.

As the antiabsorptive effect was seen only in the jaundiced infants receiving phototherapy, and the effect disappeared after regression of the jaundice and stopping the phototherapy, it must be caused by the simultaneous action of hyperbilirubinaemia and phototherapy. These data confirm those of Rubaltelli and Largajalli in 1973 who showed a reduced transit time (which can well be attributed to the increase in the fluidity of intestinal contents) only in jaundiced infants receiving phototherapy and not in those who were not jaundiced and receiving phototherapy or healthy infants receiving no treatment. ${ }^{12}$

Finally, the present data show that jaundiced infants receiving phototherapy develop diarrhoea because of an induced secretory change in net intestinal ion transport. What then are the mechanisms responsible for it? We have shown that the bile from jaundiced, photoirradiated Gunn rats has an antiabsorptive effect in the rat jejunum in vivo. ${ }^{13}$ Among the substances that are present in such bile is unconjugated bilirubin in large amounts, and we $\mathrm{w}^{13}$ and others ${ }^{14}$ have shown that unconjugated bilirubin is an intestinal secretagogue. Thus although we did not investigate the potential role of other compounds found in bile (such as bile acids or other photo products of bilirubin) we can assume that unconjugated bilirubin is, at least in part, responsible for the observed effect on ion and water transport.

\section{References}

1 Jhon E. Complication of phototherapy in neonatal hyperbilirubinemia. Aust Paediatr J 1975;11:53-5.

2 Bakken AF. Temporary intestinal lactase deficiency in lighttreated jaundiced infants. Acta Paediatr Scand 1977;66:91-6.

${ }^{3}$ Ebbesen F. Gut transit time and lactose malabsorption during phototherapy. I. Acta Paediatr Scand 1980;69:65-8.

4 Ebbesen F. Gut transit time and lactose malabsorption during phototherapy. II. Acta Paediatr Scand 1980;69:69-71. 
1164 De Curtis, Guandalini, Fasano, Saitta, and Ciccimarra

${ }^{5}$ Bujanover Y, Schwartz G, Milbaner B, Peled Y. Lactose malabsorption is not a cause of diarrhea during phototherapy. $J$ Pediatr Gastroenterol Nutr 1985;4:196-8.

6 De Curtis M, Saitta F, Matteoli M, Paludetto R, Ciccimarra F, Guandalini S. Evidence for secretory type diarrhea in infants treated by phototherapy. Lancet 1982;i:909-10.

7 Edmonds LJ, Godfrey R. Measurement of electrical potentials of the human rectum and pelvic colon in normal and aldosterone treated patients. Gut 1970;11:330-7.

${ }^{8}$ Savage MO, Jefferson IG, Dillon MJ, Milla PJ, Honour JW, Grand DB. Pseudo hypoaldosteronism: severe salt wasting in infancy caused by generalized mineralcorticoid unresponsiveness. J Pediatr 1982;101:239-42.

9 Krejis GJ, Fordtran JS. Diarrhea. In: Sleisenger MH, Fordtran JS, eds. Gastrointestinal diseases. Philadelphia: WB Saunders, 1983:257-80.

${ }^{10}$ Blanc B. Biochemical aspects of human milk comparison with bovine milk. World Rev Nutr Diet 1981;36:1-89.
11 De Curtis M, Senterre J, Rigo J, Putet G. Carbohydrate-derived energy absorption in preterm infants fed human milk or formula. Arch Dis Child 1986;61:867-70.

12 Rubaltelli FF, Largajolli G. Effects of light exposure on gut transit time in jaundiced newborns. Biol Neonate 1973;62:146-8

${ }^{13}$ Guandalini S, Fasano A, Albini F. et al. Unconjugated bilirubin and the bile from light-exposed Gunn rats inhibit intestinal water and electrolyte absorption. Gut 1988;29:366.

14 Whitington PF, Olsen WA, Odell GB. The effect of bilirubin on the function' of hamster small intestine. Pediatr Res 1981;15: 1009-14.

Correspondence to Dr M De Curtis, Department of Paediatrics, Second School of Medicinc, Via S Pansini 5, 80131 Naples, Italy.

Accepted 2 February 1989 